\title{
The Role of Cities in the Sharing Economy: Exploring Modes of Governance in Urban Sharing Practices
}

\author{
Jenny Palm, Karolina Södergren * and Nancy Bocken \\ International Institute for Industrial Environmental Economics (IIIEE), Lund University, P. O. Box 196, \\ 22100 Lund, Sweden; jenny.palm@iiiee.lu.se (J.P.); nancy.bocken@iiiee.lu.se (N.B.) \\ * Correspondence: karolina.sodergren@iiiee.lu.se; Tel.: +46-46-222-00-00
}

Received: 12 November 2019; Accepted: 10 December 2019; Published: 12 December 2019

\begin{abstract}
Cities have for a long time been key actors in sustainable urban development, and in recent times, also for the sharing economy, as they provide a fertile breeding ground for various sharing initiatives. While some of these initiatives build on existing practices and infrastructures such as public libraries and repair workshops, others require the involvement of private companies, as in the case of car sharing. The sharing economy might therefore require a significant reinterpretation of the role of local governments, businesses and citizens, which in turn might imply a complex re-organisation of governing. This article will explore what potential roles cities might have in governing the sharing economy. Four Swedish cities serve as case studies for this purpose: Stockholm, Gothenburg, Malmö and Umeå. City data was collected primarily through qualitative means of investigation, including workshops, interviews and desk research. In Malmö, additional participatory observations were conducted on the testbed Sege Park. Results were analysed with a framework developed for understanding the various governing roles for cities in the sharing economy. Three dominant modes of governing were identified and discussed: governing by provision and authority; governing by partnership and enabling; and governing through volunteering. The four cities made use of all three governing modes, although with a primary focus on governing by authority and governing through partnership. When characterised by governing through volunteering, projects were always initiated by the city, but then run formally by an NGO. While all governing modes may have a role and a purpose in the sharing economy, it is still important that cities reflect upon what are their actual implications. Risks include a collaborative governing mode out-competing some businesses, for example, and a self-governing mode reducing the action space of the volunteer sector.
\end{abstract}

Keywords: sharing economy; sharing cities; sustainable urban governance; sharing business models; sustainable business models

\section{Introduction}

Cities have long been key actors as planners and governors for sustainable urban development [1]. More recently, cities have also become a breeding ground for new sharing economy initiatives [2]. In a sharing economy, under-utilised assets are shared in order to optimise resource use. Individuals and families rent or borrow their assets to other people, which can be contrasted with a gig economy in which individuals offer their services to companies on a part-time basis [3].

Sharing platforms are tools that enable citizens to share, lend, sell and rent resources. Such sharing activities have the potential to promote more efficient use of resources and reduce the environmental impacts from consumption $[4,5]$. The new frontier in the sharing economy is called 'prosumers', and commonly refers to the formation of energy sharing communities between local inhabitants and utility companies [6,7]. The potential for sustainability of the sharing economy is still debated and 
needs further investigation [8]. This, however, will not be the focus for this paper. Rather, we zoom in on the different roles that cities may adopt in governing the sharing economy.

In some cases, cities may be overwhelmed by the emergence of a great variety of start-ups, e.g., in the area of mobility (e.g., car sharing, taxi services), and are forced to catch up by developing policies encouraging or inhibiting the emergence of such services. Other cities take a much more proactive role by shaping the new sharing initiatives. Examples of the latter involve the establishment of tool libraries or tool pools where people may borrow tools at no or low cost $[9,10]$. In this article, we will analyse the different roles local governments have taken in the sharing economy in four Swedish cities.

The potential for cities to leverage different resource-efficient sharing initiatives is potentially high, but at the same time not limitless. Local governments have authority in a restricted geographic area, with limited space for infrastructure, initiatives and services. Local governments need to work in governance processes, made up of partnerships and network-orientated decision-making in a sophisticated interplay between public, private and non-profit organisations [11]. Cities need to mobilise external actors (and their resources) for the formulation and implementation of complex cross-boundary issues such as sustainability, circular economy, sharing and experimentation [12]. Cities are encouraged to be at the forefront of these processes, and when doing so, the interests of external actors need to be integrated into local policy-making. At the same time, cities still need to carry out their compulsory duties and fulfil their responsibilities for providing welfare services to their citizens. Engagement in experimentation and sharing, for example, then takes resources from the cities and influences how they can perform their regulatory tasks. Acquier et al. [13] discuss the need to understand the complex and sometimes contradictory objectives cities have when advising them on how to engage in the sharing economy. Cities are supposed to navigate between requirements such as acting in the interest of the public and working on digital platforms without causing any negative externalities [13].

On the one hand, it is not obvious that a local government should engage in the sharing economy. It might be better to leave this space open for private and voluntary initiatives to enter. On the other hand, in countries like Sweden, where the voluntary sector has traditionally focused on sports and leisure, this means the sharing economy might never take off [6]. Yet, the sharing economy could have many benefits for municipal development and democratisation [14]. May et al. [15], for example, argue that digital sharing platforms could be a way for cities to pursue a more attractive image. This, however, requires a reinterpretation of the role of local governments, businesses and citizens, which in turn implies a complex re-organisation of governing. Cities might need to explore new modes of governance [16].

In this article, we address the following research question: What potential roles do cities have in governing the sharing economy? The dilemmas faced by cities when engaging in the sharing economy are described, and an analytical framework for discussing what sharing issues municipalities should engage in, when and why, is presented.

\section{Background}

This section discusses the sharing economy in a local context, followed by a background on how to study the governing of the sharing economy.

\subsection{Sharing Economy: Background and Local Contexts}

While not a novel phenomenon per se [17], sharing has gained popularity in recent years through the ICT and social networks (e.g., digital platforms), enabling a sharing economy $[15,18]$. This has been called an "idea that will change the world" through its potential contribution to future economic activity [19].

Within the sustainability discourse, the sharing economy has been endorsed as a means for dematerialising our economies $[2,20]$. In the background lie growing concerns about the unsustainable 
consumption patterns characterising our times and the resulting over-exploitation of natural resources that lead to increasing pollution, climate change, biodiversity loss, etc. [2,21].

In academia, the sharing economy has mainly been studied as a solution that leverages the idling capacity of goods and services by offering access over ownership [2]. Critics, however, claim that it is becoming a 'catch-all term', and call for a more detailed definition [22], notably because semantic confusion can lead to the concept being misused in ways that go against its intended meaning. Similar to the term 'green washing', 'share washing' has been used to describe such situations in which companies make illicit linkages between their core business and sharing as a sustainable consumption practice [2]. 'Platform capitalism' or 'neoliberalism on steroids' are other phrases that have been used to describe the controversy surrounding the definition of the sharing economy [23].

Taking the above into account and contrasting the sharing economy with terms like collaborative consumption, the gig economy, peer-to-peer economy, circular economy, and consumer-to-consumer economy, Acquier et al. [24] proposed an organising framework for the sharing economy that rests upon "three foundational cores". Visible in Figure 1 below, these are: (1) access economy (e.g., the sharing of underutilised assets for optimising resource use), (2) platform economy (e.g., digital platforms mediating decentralised exchanges among peers), and (3) community-based economy (e.g., coordination through "non-contractual, non-hierarchical or non-monetized forms of interaction") [24].

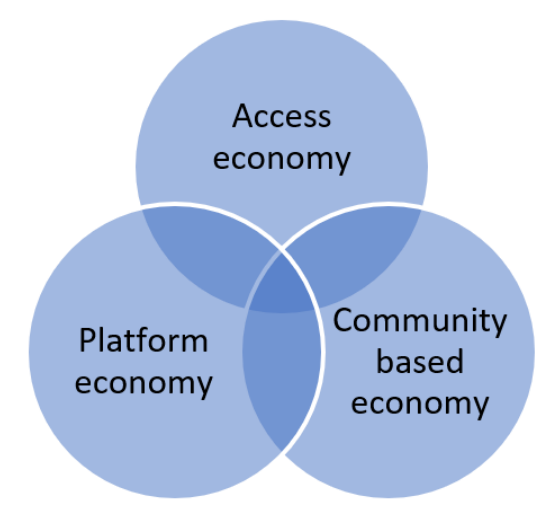

Figure 1. Conceptual underpinnings of the sharing economy. Borrowed from Acquier et al. [24].

Cities make up a particularly fertile breeding ground for sharing economy initiatives [25]. Davidson and Infranca [26] discussed how proximity and density features of urban environments bring about, e.g., agglomeration benefits. Reduced transportation costs and access to a diverse labour market are some of the factors that allow for increased productivity and economic growth in cities. A deeper pool of sellers and buyers foster specialisation, and thus the provision of goods and services that may otherwise not exist locally. The development of new products and services is also linked to the rapid information exchanges that are enabled by modern infrastructure in cities, which in turn help spur innovation.

Providing a similar logic, May et al. [15] stated that the "increasing urbanization and densification of the population helps smooth the friction of the sharing economy". In addition, conversely, according to Davidson and Infranca [26] the sharing economy is also "an agent of urban transformation". This is due to its potential impact on the economic, physical, geographical and social landscapes in cities. Hofman et al. [27] believe that the public sector has mainly acted as a regulatory body in the sharing economy, neglecting other potential roles as customers and platform providers. They undertake a theoretical analysis of how the different roles a city can take in the sharing economy relate to four different values: professionalism, efficiency, service, and engagement. They find opportunities and challenges of each role for the four public values, but conclude that there is a need for empirically based research on the subject. This article seeks to contribute in this exact regard. 
Across the globe, cities have taken different approaches to the sharing economy, with regard to both its opportunities and challenges. Developments are emerging from collaborative initiatives such as the 'sharing cities' network, culminating in November 2018 with a Sharing Cities Declaration [10]. In Sweden, the sharing economy has been described as fairly under-developed as compared to other countries [15]. The majority of companies working in the sharing economy are still in a start-up phase, and thus have a low level of revenue. That said, Sweden is seen to have good conditions for furthering and benefitting from the sharing economy. Key factors include high levels of employment, innovative entrepreneurship, specialisation in IT and communication services, use of internet and mobile phones, and strong public interest in sustainability related matters [18]. This is reflected in the mapping and analysis of sharing services and initiatives in Swedish cities provided by Markendahl et al. [10], as well as in the constant increase of digital sharing platforms operating within national borders. A 2016 survey undertaken by Nordea also showed an annual increase in sharing economy 'users' of 3\%, reaching approximately $13 \%$ of the Swedish population [18].

\subsection{Governing the Sharing Economy}

Palm et al. [9] claimed that achieving sustainable consumption required a reinterpretation of the role of public organisations, businesses and citizens because of the "complex challenges and institutional contradictions for governance" that it entails. This is in line with previously developed theories on the multi-level governance and dispersion of power that characterises our modern society [28-30].

In relation to governing the sharing economy, the need for "tougher rules" has been expressed in, e.g., The Guardian [31]. Lacking are policy guidelines ensuring that both providers and consumers are protected in sharing activities. Indeed, Cannon and Summers [32] went as far as arguing that "regulation is often the most significant barrier to future growth for sharing economy firms".

Murillo et al. [23] believe that the sharing economy should be "of particular interest to governments and public authorities since it is estimated that $70 \%$ of Europeans and $72 \%$ of Americans are involved in SE [sharing economy] activities" (p. 66). Highlighting situations in which national governments fail to establish an appropriate regulatory environment, however, they notice that "local governments are the ones that must carry the burden of taxing firms and enforcing law" (p. 70). This is also recognised by Davidson and Infranca [26] when discussing the sharing economy as an urban governance challenge, pointing to the intrinsic dependences between sharing activities and specific urban conditions.

Indeed, local or "city governments around the world are increasingly adopting policies to regulate some forms of sharing" [14]. Building upon a framework for urban climate governance developed by Bulkeley and Kern [12], Zvolska et al. [14] suggested the different roles that cities assume when governing urban sharing are: governing by regulation, governing by provision, governing by enabling, and governing by consumption. We will come back to this next, when discussing our analytical framework.

\section{City Engagement in the Sharing Economy-An Analytical Framework}

To be able to discuss city engagement in the sharing economy, we develop an analytical framework that can help with this examination. The framework is inspired by Bulkeley and Kern [12] and Zvolska et al. [14]. The extended typology includes five different modes of governing based on the type of capacity cities can have or take in different settings:

- Self-governing or governing by example, which relies on the organisational capacity of the municipality to manage its own operations;

- Governing by provision, which is related to the municipal role as provider of different goods and services;

- Governing by authority, which concerns municipal ability to mandate a certain behaviour and impose sanctions if such a mandate is not followed. 
- Governing by enabling, which refers to the municipality's capacity to persuade and encourage behaviour through the use of positive incentives such as subsidies, information campaigns, and facilitation of different kinds of initiatives.

- Governing by partnership, which is characterised by an equal relationship between the municipality and other actors. Cities are one among several actors in a project/partnership, and has no formal steering power over the other members.

In Sweden, a different model has been used in the project "Malmö Innovation Arena" to discuss what role the city could and should adopt in relation to innovations. In Malmö Innovation Arena, focus has been placed on when and how much the city of Malmö should engage in innovation processes, and when to stay out and give space for other actors to take the lead. The important parameters in this model are related to three different groups of actors (the city, businesses and volunteer organisations) as well as to who initiates, decides and implements various solutions. Table 1 presents a combination of the frameworks and ideas suggested by Bulkeley et al., Zvolska et al., and Malmö Innovation Arena.

Table 1. Governing roles for cities in the sharing economy.

\begin{tabular}{cccc}
\hline & $\begin{array}{c}\text { Governing by Provision } \\
\text { and Authority }\end{array}$ & $\begin{array}{c}\text { Governing by } \\
\text { Partnership and } \\
\text { Enabling }\end{array}$ & $\begin{array}{c}\text { Governing through } \\
\text { Volunteering }\end{array}$ \\
\hline Initiator & Local & $\begin{array}{c}\text { Local government } \\
\text { together with others }\end{array}$ & $\begin{array}{c}\text { Citizens or } \\
\text { organisations (NGOs) }\end{array}$ \\
\hline Decision made by & Local government & $\begin{array}{c}\text { Shared between involved } \\
\text { partners }\end{array}$ & By the initiator \\
\hline Activities run by & Local government & $\begin{array}{c}\text { Local government and } \\
\text { partner }\end{array}$ & By the initiator \\
\hline The public sector has & Steering role & Cooperative role & $\begin{array}{c}\text { Role when needed to } \\
\text { stimulate and facilitate } \\
\text { implementation }\end{array}$ \\
\hline
\end{tabular}

In a process characterised by governing by provision and authority, the city initiates the issue at hand. The results can be defined from the beginning of a project, resources are calculated, and all decisions are made within the city administration.

In governing by partnership and enabling, the issue is initiated and run collaboratively with others. From the city's point of view, the outcome is more open-ended, decision-making is done in networks of public-private partnership and implementation in collaboration with all stakeholders.

In governing through volunteers, the results of a project are uncertain, and not easily predictable by the city administration. The process lies in the hands of other actors and the role of the city is mainly to support or facilitate these processes. Reasons for cities to engage in volunteer initiatives include that the cities' financial or social vitality is strengthened, the accessibility to public spaces is increased, as well as the quality in the location in which the initiative is implemented. The initiative, however, is never launched by the city, and always by private actors and/or civil society.

Below, this framework will be used to analyse how four Swedish cities have considered their participation in the sharing economy.

\section{Methods}

The data collection was conducted as part of Sharing Cities Sweden (www.sharingcities.se), which is an initiative that aims to "develop world-leading test-beds for the sharing economy in Stockholm, Gothenburg, Malmö and Umeå". Qualitative methods were used to gather research data, including workshops, semi-structured interviews and participant observation. 
For each city, we started by collecting documents, articles and policy papers related to sharing. We then conducted a workshop with representatives from all four cities in April 2019, and followed up with more detailed interviews in September and November 2019.

The workshop was organised as part of the Lund Sustainability Week on 8 April 2019. The whole event gathered over 80 participants from four Swedish cities-Malmö, Gothenburg, Stockholm and Umeå-as well as academics and other stakeholders interested in Sharing Cities. In the morning, different sharing projects were presented. In the afternoon, twenty participants were invited from Umeå, Gothenburg, Stockholm, and Malmö cities for a closed workshop held partly in English (moderation) and partly in Swedish (subgroup discussion). During the workshop, participants were grouped city-wise, i.e., representatives from the same city were placed in the same group. Each group was chaired by a researcher who also took notes from the discussions. Four main questions were discussed:

1. the role of the city in the sharing economy

2. the city's ambitions in the sharing economy

3. business models and future opportunities

4. the role of digitalisation in the sharing economy

We also conducted complementary interviews with representatives from the three cities, to follow up on how they work with sharing initiatives (Gothenburg, Malmö and Umeå). The interviews were semi-structured covering the following themes: Sharing projects, content; Engaged actors/organisations; What does the engagement look like, mechanisms for engagement (facilitating and conducting experimentation, taxes, regulations, procurement, partnerships, financing, etc.); Problems; Possibilities; What do you envision the city's role in the future; and Other.

Additionally, in Malmö, participatory observations have been done at 24 dialogue meetings in their testbed Sege Park since June 2018. According to the city plans, there will be up to 900 dwellings in Sege Park by 2025. The development process is supposed to be done using a sustainable approach with a specific focus on creating a low-carbon district and innovative sharing solutions. The researchers have participated in 24 dialogue meetings where property developers and city representatives met to discuss how to develop the area and what solutions to invest in. During the meetings, field notes were written, addressing the dialogues between participants. Fifteen interviews were also conducted focusing on the collaborative process in Sege Park.

The interview questions in Sege Park were semi-structured and covered the following themes: the interviewees' professional background and current professional role, the collaborative planning process and how it was (or was not) related to the work processes in Sege Park, experiences so far with the process and descriptions of how the process and included issues discussed at the meeting played out, interaction between the participants and finally, which parts had worked well and what improvements could potentially be made. A summary of the methodological approach used for this research is available in Figure 2 below.

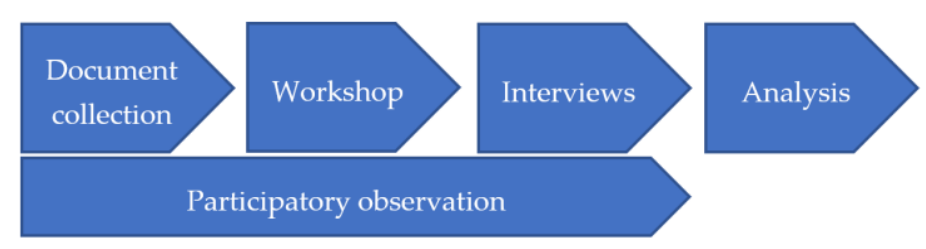

Figure 2. Methods applied for this research.

We will now use examples of city engagements to discuss how the cities are governing the sharing economy, as well as how they think about it. 


\section{Results: Different City Roles in the Sharing Economy}

Swedish cities have invested in various solutions to enable their citizens to move towards sharing. Examples of how cities contribute through different governing modes have been discussed in an earlier contribution [9]. In this study, we will analyse how cities regard their roles in the sharing economy. The results are organised according to the three governing modes presented in the analytical framework above.

\subsection{Governing by Self-Government, Provision and Authority}

Governing by self-government, provision and authority includes activities where the city manages its own operations, provide goods or services or uses sanctions, for example, to mandate a behaviour.

During the workshop, all four cities mentioned that it was important that they adopt a role as a regulator to be able to attain a quick transformation towards the sharing economy. By taking an authoritative role, the city can "shape" the urban environment, as one of the representatives expressed it. The cities used public procurement actively for this purpose. For example, car sharing was procured by the cities as a way to contribute to a sharing economy as well as to environmental sustainability with the assumption that it reduces the numbers of cars needed by the city.

During the workshop, city planning was emphasised as an important way for all the cities to contribute to a sustainable and circular society. Not only car-free districts where mentioned, but also the possibility of planning for mobility as a service (MAAS) by including transportation hubs in the city planning process. Umeå thought that it was important for the city to also be engaged through its authoritative function to be able to guarantee that sharing was something that all citizens could take part of. Umeå had found it easier to establish private sharing solutions such as carpooling in middle-class areas, compared to areas with socio-economic problems. Private carpooling companies hesitated to park their cars in less wealthy areas, because of bad experience with demolished cars. This experience was shared by Stockholm and Malmö. An important role for the city, which was highlighted during the workshop, was to make sure that all citizens benefitted from sharing services. Otherwise, the risk is that only citizens in favourable socio-economic situations would be able to take part in the sharing economy. From this perspective, the city representatives thought that the city should use authoritative means such as planning and public procurement to contribute to the development of a local sharing economy.

As mentioned above, Sege Park in Malmö is a testbed for sharing solutions. Over 30 sharing solutions have been up for discussion so far (field notes 28 February 2018). When it comes to the governing process related to these sharing solutions, it is not so clear what governing approach the city of Malmö has used. The process has been characterised by all three approaches (self-government, collaborative and volunteers). We will address the collaborative and volunteer aspects further down. In relation to governing by self-government, provision and authority, the city of Malmö has regulated that sharing should be a main characteristic of Sege Park. This was an explicit requirement in the land allocation process that property developers needed to take into consideration. In the city's sustainability strategy, it says that "Sege Park shall be a testbed for how sharing solutions can be used in the city district area". In the land allocation process, the property developers needed to show how they planned for sharing services, such as having premises that could be used for sharing in buildings, car and electric bike pools, outdoor barbecue "kitchens" to be shared, etc. The city used the zoning plan to create a car-free neighbourhood, which also encouraged public transportation and car sharing.

However, the city has not always been prepared to support sharing solutions even if they had the authority to do so. Sege Park in Malmö has a sustainability approach, and the property developers in the area planned for installing PVs on the roof and on the ground, and for developing a micro grid which would make it possible to share electricity among the different property developers. The city of Malmö was not prepared to distribute space in the zooning plan for PVs in the green areas that the city owned and controlled. Moreover, in relation to the micro grid, the city chose not to act. For regulative reasons, it is not possible to have a micro grid where you transport electricity between 
different buildings if the buildings have different owners, as is the case in Sege Park. The city of Malmö could, however, have asked the Swedish Government if Sege Park could be a testbed for trying this out. However, they chose not to.

To conclude, the cities have applied governing by self-government, provision and authority to enhance a sharing economy. There is, however, also one example of when they deliberately chose not to use this governing mode, and thereby, hindered the implementation of different sharing solutions.

\subsection{Governing by Partnership and Enabling}

Governing by partnership and enabling is characterised by cooperation between the municipality and other actors, as well as by the city using positive incentives to encourage a behaviour.

This was the mode that the four cities highlighted as the most prominent one for developing a sharing economy. In general, the city was seen to have a key role in facilitating and enabling various sharing initiatives. They emphasised their role as owners of certain sharing initiatives such as "smartakartan.se" (the smart map), which is a digital map highlighting what kind of sharing solutions are available in the city and where they are located.

All four cities also agreed that digitalisation was a critical enabling factor for sharing, through apps, digital platforms, etc. The cities felt that they had an important role in developing those ICT tools, but also that it required many man-hours for development and maintenance. This time-consuming work was seen as difficult for a private actor to engage in, which more or less forced the cities to take a role in the development process. Swedish cities also have a lot of data and statistics stored, such as travel patterns and socio-economic data, which is relevant for many sharing services. The cities were willing to share this type of data, as long as it did not violate any regulations.

In Sege Park, Malmö city emphasised the collaborative governing mode from the start of the project and made clear that in order to fulfil the goal of Sege Park as a testbed for sharing, all actors involved needed to contribute.

The city was prepared to facilitate sharing solutions through planning, organising workshop and study visits, inviting experts and practitioners, and providing support with finding funding to try out different sharing solutions. The building developers needed to decide what sharing activities they wanted to invest in and how they would collaborate among themselves around different sharing services. They had to fill out a questionnaire mentioning what kind of sharing services they had in mind, how these would be organised and paid for, and if the services would be available for their tenants only or for anyone.

This collaborative mode worked well for some property owners, while others chose not to participate. The reason for not contributing was that the developers believed that they had been allocated small land areas, which according to them made it impossible to be involved in the sharing solutions discussed:

We do not have the possibility to work with sharing spaces because we have not so much land allocated to us. Thus, so far we have not been able to contribute and we will continue to have less opportunities to participate in sharing solutions. (Property developer 7)

As seen in the quotation above, although not the case, this property developer had interpreted discussions in a way that suggested that all sharing solutions need space.

Other developers felt that too much time was spent on developing sharing solutions, "without guidance or direction". They lacked concrete examples on successful sharing solutions and thought that sharing services came with risks that were too great.

Sharing has not been discussed in relation to existing sharing solutions in other areas. / ... / We have a list with sharing solutions, but we have not discussed how this will work in practice. (Property developer 9)

The property developers lacked evaluations and wanted more knowledge about what the results have been in other areas where sharing solutions have already been implemented. 
Several of the developers also questioned the idea that building developers and the city should plan for future sharing services for residents without having any knowledge of future demand:

This is the difficult part with sharing. We cannot force the future residents to use them. And it is hard to know what the future demand for sharing solutions will consist of. We can prepare for sharing, but not decide what the future residents will do. (Property developer 2)

Another property developer said:

The sharing group becomes speculative. We spend time on things where we don't know if this is the right solution to work with. We don't know which sharing solution will be the one asked for. (Property developer 12)

These property developers thought that sharing services should be developed by the citizens in relation to their demand, which also takes us to the next governing mode.

\subsection{Governing through Volunteering}

Governing through volunteering emphasises the role of NGOs and citizens, and that it is volunteers who should take a lead in developing the sharing economy.

During the workshop with the cities, a perspective that was often put forward was the importance of the sharing economy as led by the demands from the users. As described above, it was, however, a critique in Sege Park that the citizens were not involved in the development of the sharing economy. The potential result, highlighted by actors in Sege Park, could be that sharing solutions were developed without any existing demand. Another problem could be that commercial interests conquer the area, and leave no room for other actors. This was discussed in a debate article recently published by one of Sweden's biggest newspaper, Dagens Nyheter [33]. In the article, several volunteer organisations came together and criticised Swedish municipalities for out-competing NGO activities, including environmental, social and human rights work to promote social or political change. They felt that when Swedish municipalities start to run repair workshops together with café services, they outcompete "the social and local economy", referring to the volunteer sector and NGOs.

A challenge raised multiple times by the cities during the workshop was related to finding sustained financial resources for initiatives with volunteer engagement. Sharing experiments that were done with volunteers were considered short-time engagements. At the same time, there were several examples of successful sharing services where the civil society had a leading role, for example a toy library in Gothenburg and clothing exchange days in Malmö. These projects favour social inclusion as well as sustainability, according to the cities.

Gothenburg emphasised that they wanted the "local society" to provide social services. They saw the role of the city as mainly supportive, and Gothenburg was the city that reflected most upon governing through volunteer mode during the workshop. They believed that the role of the city was to provide a kind of 'payback' for social services, which would give more security to private initiatives.

\section{Conclusions}

The aim with this article was to increase the understanding of the different roles a city might take in governing the sharing economy. The idea was not to evaluate or assess how the cities have performed, but to identify and reflect upon different governing modes used by local governments.

The four Swedish cities that were analysed relate to all three governing modes that were defined: governing by provision and authority; governing by partnership and enabling; and governing through volunteering. However, in reality, examples characterised by authority and partnership modes of governance dominated the discussions. One possible explanation for this is that a high involvement of the cities is needed initially, to transform the economy to a sharing economy. A strong actor, such as a city, might be needed to lead this process, in particular when private companies compete for space and market share. Indeed, the proliferation of scooters and bike sharing schemes within city 
boundaries pursued by private companies indicates that intervention and more of an authority and partnership role adopted by the cities would be desirable. May et al. [15] highlight 'trust' as a critical lever for making the sharing economy work. Swedish cities as public actors are usually seen as highly trustworthy and have been important trust creators for many experimental projects, such as in the sharing test beds in the four cities [9].

Having strong cities leading the transformation towards a sharing economy also comes with certain problems. When cities take the lead in the sharing economy, there is a risk that they out-compete the volunteer sector. It was expressed during interviews and in the workshop that when governing through volunteering, cities usually initiate the sharing solution and then hand over to an NGO or an individual to take care of the day-to-day activities. The cities' experience it to be difficult to sustain sharing activities where volunteers play a major role. An explanation for this lack of perseverance could be that the cities initiated solutions that did not attract enough interest from the public, contributing to the engagement quickly fading out. The role of volunteers and how it relates to the role of cities needs further investigation in the future to understand why volunteers have difficulty in maintaining engagement.

Another problem raised by the property developers in the testbed Sege Park in Malmö was that there may be a mismatch between the sharing services cities offer and the services citizens want. The risk is that the city ends up with many sharing solutions that no one is using. An increased involvement of volunteers could here be a way to close such a potential gap. The strength of the volunteer sector lies in its proximity to citizens as well as in their localised understanding of existing needs. This knowledge might disappear if cities start to dominate the process.

Cities can also resist sharing solutions, like Malmö did when opposing shared PV parks in Sege Park. Cities as barriers for the development of a sharing economy is another perspective that requires further research.

In conclusion, all governing modes are needed in the development of a sustainable sharing economy. For cities, however, it is important to reflect upon what the implications are of different governing modes.

Author Contributions: Responsible for the Introduction were J.P., K.S. and N.B.; Background, K.S.; Analytical framework, J.P.; methodology, J.P., K.S. and N.B.; analysis, J.P. with input from K.S. and N.B.; Conclusions, J.P., K.S. and N.B.; revision, J.P. and K.S.

Funding: This research was funded by VINNOVA, for the Strategic Project Sharing Business Models within the Sharing Cities program, grant number 2018-04646 and by the Swedish Energy Agency project no 46016-1 "Smart symbiosis-collaboration for common resource flows".

Acknowledgments: We would like to acknowledge the support of the Lund University IIIEE teams in facilitating the cities workshop.

Conflicts of Interest: The authors declare no conflict of interest. The funders had no role in the design of the study; in the collection, analyses, or interpretation of data; in the writing of the manuscript, or in the decision to publish the results.

\section{References}

1. Fenton, P.; Gustafsson, S.; Ivner, J.; Palm, J. Sustainable energy and climate strategies: Lessons from planning processes in five municipalities. J. Clean. Prod. 2015, 98, 213-221. [CrossRef]

2. Curtis, S.K.; Lehner, M. Defining the sharing economy for sustainability. Sustainability 2019, $11,567$. [CrossRef]

3. De Stefano, V. The rise of the just-in-time workforce: On-demand work, crowdwork, and labor protection in the gig-economy. Comp. Labor Law Policy J. 2015, 37, 471. [CrossRef]

4. Martin, C.J.; Upham, P.; Klapper, R. Democratising platform governance in the sharing economy: An analytical framework and initial empirical insights. J. Clean. Prod. 2017, 166, 1395-1406. [CrossRef]

5. Frenken, K. Sustainability perspectives on the sharing economy. Environ. Innov. Soc. Transit. 2017, $23,1-2$. [CrossRef] 
6. Magnusson, D.; Palm, J. Come together-the development of Swedish energy communities. Sustainability 2019, 11, 1056. [CrossRef]

7. Kooij, H.-J.; Oteman, M.; Veenman, S.; Sperling, K.; Magnusson, D.; Palm, J.; Hvelplund, F. Between grassroots and treetops: Community power and institutional dependence in the renewable energy sector in Denmark, Sweden and the Netherlands. Energy Res. Soc. Sci. 2018, 37, 52-64. [CrossRef]

8. Schor, J. Debating the sharing economy. J. Self-Gov. Manag. Econ. 2016, 4, 7-22.

9. Palm, J.; Smedby, N.; McCormick, K. The role of local governments in governing sustainable consumption and sharing cities. In A Research Agenda for Sustainble Consumption Governance; Mont, O., Ed.; Edward Elgar Publishing: Cheltenham, UK, 2019.

10. Markendahl, J.; Hossain, M.I.; Mccormick, K.; Lund, T.; Möller, J.; Näslund, P. Analysis of sharing economy services: Initial findings from sharing cities Sweden. Nord. Balt. J. Inf. Commun. Technol. 2018, 2018, $239-260$.

11. Wihlborg, E.; Palm, J. Who is governing what? Governing local technical systems-An issue of accountability. Local Gov. Stud. 2008, 34, 349-362. [CrossRef]

12. Bulkeley, H.; Kern, K. Local government and the governing of climate change in Germany and the UK. Urban Stud. 2006, 43, 2237-2259. [CrossRef]

13. Acquier, A.; Carbone, V.; Massé, D. How to create value (s) in the sharing economy: Business models, scalability, and sustainability. Technol. Innov. Manag. Rev. 2019, 9, 5-24. [CrossRef]

14. Zvolska, L.; Lehner, M.; Voytenko Palgan, Y.; Mont, O.; Plepys, A. Urban sharing in smart cities: The cases of Berlin and London. Local Environ. 2019, 24, 628-645. [CrossRef]

15. May, S.; Konigsson, M.; Holmstrom, J. Unlocking the sharing economy: Investigating the barriers for the sharing economy in a city context. First Monday 2017, 22. [CrossRef]

16. Evans, B.; Joas, M.; Sundback, S.; Theobald, K. Governing local sustainability. J. Environ. Plan. Manag. 2006, 49, 849-867. [CrossRef]

17. Belk, R. Sharing. J. Consum. Res. 2009, 36, 715-734. [CrossRef]

18. SOU. Delningsekonomi på användarnas villkor. In Swedish Governments Official Reports; 2017:26; Wolters Kluwers: Stockholm, Sweden, 2017.

19. Gregory, A.; Halff, G. Understanding public relations in the 'sharing economy'. Public Relat. Rev. 2017, 43, 4-13. [CrossRef]

20. Boons, F.; Bocken, N. Towards a sharing economy-Innovating ecologies of business models. Technol. Forecast. Soc. Chang. 2018, 137, 40-52. [CrossRef]

21. Heinrichs, H. Sharing economy: A potential new pathway to sustainability. Gaia-Ecol. Perspect. Sci. Soc. 2013, 22, 228-231. [CrossRef]

22. Belk, R. Sharing versus pseudo-sharing in Web 2.0. Anthropologist 2014, 18, 7-23. [CrossRef]

23. Murillo, D.; Buckland, H.; Val, E. When the sharing economy becomes neoliberalism on steroids: Unravelling the controversies. Technol. Forecast. Soc. Chang. 2017, 125, 66-76. [CrossRef]

24. Acquier, A.; Daudigeos, T.; Pinkse, J. Promises and paradoxes of the sharing economy: An organizing framework. Technol. Forecast. Soc. Chang. 2017, 125, 1-10. [CrossRef]

25. McLaren, D.; Agyeman, J. Sharing Cities: A Case for Truly Smart and Sustainable Cities; MIT Press: Cambridge, MA, USA, 2015.

26. Davidson, N.M.; Infranca, J.J. The sharing economy as an urban phenomenon. Yale Law Policy Rev. 2015, 34, 215.

27. Hofmann, S.; Sæbø, Ø.; Braccini, A.M.; Za, S. The public sector's roles in the sharing economy and the implications for public values. Gov. Inf. Q. 2019, 36, 101399. [CrossRef]

28. Rhodes, R.A.W. Understanding Governance: Policy Networks, Governance, Reflexivity and Accountability; Open University Press: Buckingham, UK, 1997.

29. Pierre, J. Debating Governance: Authority, Steering, and Democracy; Oxford University Press: Oxford, UK, 2000.

30. Peters, G.; Pierre, J. Multi-level governance and democracy: A Faustian bargain? In Multi-Level Governance; Bache, I., Flinders, M., Eds.; Oxford University Press: New York, NY, USA, 2004; pp. 75-91.

31. Jericho, G. The dark side of Uber: Why the sharing economy needs tougher rules. The Guardian, 18 April 2016. 
32. Cannon, S.; Summers, L.H. How Uber and the sharing economy can win over regulators. Harv. Bus. Rev. 2014, 13, 24-28.

33. Stuart Hamilton, U.; Skogar, P. DN debatt-Kommunal dumpning slår sönder den sociala ekonomin. Dagens Nyheter, 13 August 2019.

(C) 2019 by the authors. Licensee MDPI, Basel, Switzerland. This article is an open access article distributed under the terms and conditions of the Creative Commons Attribution (CC BY) license (http://creativecommons.org/licenses/by/4.0/). 